\title{
Inflammatory synovial tissue mononuclear cells release leucocyte migration inhibition factor in antigen- and mitogen-free cultures
}

\author{
TORSTEIN EGELAND, OVE J. MELLBYE, AND JAN A. PAHLE \\ From the Institute of Immunology and Rheumatology, Rikshospitalet University Hospital, Oslo, and Oslo \\ Sanitetsforening Rheumatism Hospital, Oslo, Norway
}

SUMmarY The presence of leucocyte migration inhibition factor (LIF) in supernatants from apparently antigen- and mitogen-free cultures of mononuclear cells (MNC) was studied. MNC were eluted from inflamed synovial tissue or isolated from blood. Untreated supernatants, supernatants in which any LIF had been inactivated, and culture medium were compared in their ability to affect the migration of homologous polymorphonuclear leucocytes. LIF was released by synovial tissue MNC from all of the 9 patients studied, consisting of 5 patients with rheumatoid arthritis, 2 with psoriatic arthropathy, and 2 with juvenile rheumatoid arthritis. Blood MNC of the patients and of 8 healthy blood donors did not release LIF. When synovial tissue MNC supernatants from 2 patients were examined, LIF activity increased as time of incubation was extended. In at least 2 synovial tissue MNC supernatants in which LIF had been inactivated a migration enhancement activity was revealed.

The inflamed synovial membrane of rheumatoid arthritis (RA) is heavily populated by lymphocytes, macrophage-like cells, ${ }^{1}$ immunoglobulin-containing plasma cells, ${ }^{2}$ and occasionally polymorphonuclear leucocytes (PML). ${ }^{3}$ Infiltrating cells are responsible for local immune responses, such as the production of large amounts of immunoglobulins ${ }^{4}$ and the release of lymphokines as macrophage migration inhibition factor (MIF) and lymphocyte mitogenic factor. ${ }^{5}$

Leucocyte migration inhibition factor (LIF) is a lymphokine which inhibits the migration of PML in vitro. ${ }^{6}$ LIF is produced by sensitised lymphocytes in response to antigens or mitogens. ${ }^{7}$ However, there are reports of apparently antigen- and mitogenfree incubation conditions in which LIF or MIF was produced by blood mononuclear cells (MNC) from healthy individuals, ${ }^{8}$ and from patients with infectious mononucleosis ${ }^{9}$ or connective tissue disorders. ${ }^{10}$ Recently Chattopadhyay et al. ${ }^{11}$ found spontaneous release of LIF by MNC eluted from rheumatoid synovial tissue of patients with seronegative rheumatoid arthritis (RA) but not from seropositive patients.

One of the purposes of the present investigation

Accepted for publication 9 September 1980

Correspondence to Dr T. Egeland, Institute of Immunology and Rheumatology, Fr. Qvamsgt. 1, Oslo 1, Norway. was to study further the in-vitro release of LIF by synovial tissue MNC from patients with RA and related arthritides apparently without exposing the cells to any inducing agent. In addition blood MNC from the patients were studied in the same way. An indirect leucocyte migration inhibition test first described by Clausen ${ }^{12}$ was performed, comparing each culture supernatant, the same supernatants inactivated for any LIF present, and culture medium in their ability to affect the migration of homologous PML in agarose medium.

Some investigators have reported that supernatants from certain cultures of blood MNC have shown an activity which stimulated the migration of PML. ${ }^{13-15}$ This activity is thought to be caused by another lymphokine tentatively labelled leucocyte migration enhancement factor (LEF). By comparing LIF-inactivated supernatants with culture medium in respect of their effect on PML migration we have also looked for a stimulatory activity in the supernatants.

\section{Materials and methods}

PATIENTS AND BLOOD DONORS

Synovial tissue was obtained by synovectomy from 5 patients with rheumatoid arthritis (RA), 2 patients with juvenile rheumatoid arthritis (JRA), and 2 
patients with psoriatic arthropathy (PA), all admitted to Oslo Sanitetsforening Rheumatism Hospital, Oslo, Norway. Except for 1 patient (no. 9) they were all women aged from 31 to 54 years. The patients were on salicylate, chloroquine, naproxen, ibuprofen, gold thiomalate, or prednisone. Tissue samples were taken from synovectomies performed under temporary ischaemia and general or nerve block anaesthesia. Heparinised blood was collected from 7 of these patients, in 4 patients 1 day after the operation and in 3 patients a week after. Blood samples were also taken from 3 patients with RA 1 day before and 1 day after the operation. Blood from 8 healthy blood donors served as controls.

\section{ELUTION OF SYNOVIAL TISSUE MNC}

Synovial tissue MNC were eluted according to Abrahamsen et al. ${ }^{1}$ Briefly, the tissue was minced and dissociated by treatment with crude collagenase and DNase. The cell suspension obtained was filtered and incubated in plastic culture flasks overnight at $37^{\circ} \mathrm{C}$. The cells that did not adhere to the plastic surface were harvested and the cells further purified by the Isopaque-Ficoll gradient centrifugation technique. ${ }^{16}$ After washing 3 times in Hanks's balanced salt solution without $\mathrm{Ca}^{++}$and $\mathrm{Mg}^{++}$(HBSS, Flow Laboratories, UK), the eluted cells were suspended in Medium 199 (Flow Lab.) containing $20 \%$ heat-inactivated fetal calf serum (Flow Lab.), $2 \mathrm{mM}$ glutamine (Flow Lab.), 100 $\mathrm{IU} / \mathrm{ml}$ penicilline, and $100 \mu \mathrm{g} / \mathrm{ml}$ streptomycin (Flow Lab.). Cells with an appearance similar to blood Isopaque-Ficoll-separated MNC were counted in a Burker haemocytometer and constituted approximately $70 \%$ of all eluted cells. The final concentration of the counted synovial tissue MNC was set to $3 \times 10^{6} \mathrm{MNC} / \mathrm{ml}, 1 \mathrm{ml}$ per culture tube.

With the trypan blue dye exclusion test the viability always exceeded $75 \%$ before and $50 \%$ after the cells were incubated at $37^{\circ} \mathrm{C}$ in $100 \%$ humidity and $5 \% \mathrm{CO}_{2}$. For practical reasons the incubations lasted for 48,72 , or 96 hours. Since enough synovial tissue MNC were available from 2 of the patients (nos. 2 and 7), the release of LIF was studied after various times of incubation. Blood MNC from 2 healthy individuals were also studied in the same way.

SEPARATION OF PERIPHERAL BLOOD MNC Peripheral blood MNC were separated from heparinised blood from the patients and healthy blood donors according to the method of Böyum. ${ }^{16}$ After being washed the MNC were suspended in the same medium as the eluted synovial tissue cells: $3 \times 10^{6} \mathrm{MNC} / \mathrm{ml}, 1 \mathrm{ml}$ per tube. The viability with the trypan blue dye exclusion test always exceeded
$90 \%$ before and $80 \%$ after the MNC incubation period of 48 or 72 hours at $37^{\circ} \mathrm{C}$ in $100 \%$ humidity, and $5 \% \mathrm{CO}_{2}$.

SEPARATION OF PERIPHERAL BLOOD PML

Dextran-separated buffy-coat cells from heparinised peripheral blood from healthy blood donors were used for separation of PML. The method of Böyum ${ }^{16}$ was used with a minor modification, the buffy-coat being placed directly on Isopaque-Ficoll. After centrifugation at $800 \mathrm{~g}$ for $20 \mathrm{~min}$ the pellet cells were washed as described by Anders and Natvig. ${ }^{17}$ The pellet leucocytes, on average $95 \%$ PML, were finally suspended in Medium 199 containing 10\% heat-inactivated horse serum (National Institute of Public Health, Oslo, Norway), $2 \mathrm{mM}$ glutamine, $100 \mathrm{IU} / \mathrm{ml}$ penicilline, and $100 \mu \mathrm{g} / \mathrm{ml}$ streptomycin. The concentration of PML was set to $1.6 \times 10^{8}$ $\mathrm{PML} / \mathrm{ml}$. Contaminating erythrocytes were not lysed. ${ }^{17}$ Viability always exceeded $90 \%$.

\section{PREPARATION OF AGAROSE MEDIUM}

The agarose medium was freshly prepared on each day of assaying supernatants from the cultures of blood or synovial tissue MNC. The final medium contained $1 \%$ agarose (Litex, Glostrup, Denmark), $10 \%$ heat-inactivated horse serum, $2 \mathrm{mM}$ glutamine, $15 \mathrm{mM}$ HEPES, $100 \mu \mathrm{g} / \mathrm{ml}$ of $\mathrm{NaHCO}_{3}, 100 \mathrm{IU} / \mathrm{ml}$ penicilline, and $100 \mu \mathrm{g} / \mathrm{ml}$ streptomycin in Medium 199. $4.5 \mathrm{ml}$ agarose medium was placed on a Petri dish (Millipore, USA), $5 \mathrm{~cm}$ diameter, and the gel was allowed to set. Fourteen wells of $3 \mathrm{~mm}$ diameter were cut in each gel plate.

\section{INDIRECT LEUCOCYTE}

\section{MIGRATION INHIBITION TEST}

After 24-120 hours of incubation of $1 \mathrm{ml}$ of blood or synovial tissue MNC suspensions, the suspensions were centrifuged at $400 \mathrm{~g}$ for 15 minutes, and $0.8 \mathrm{ml}$ of the supernatant was removed and divided into 2 parts of $0.4 \mathrm{ml}$ each. One part served as a test supernatant. The other part was exposed to $80^{\circ} \mathrm{C}$ for $30 \mathrm{~min}$, which has been shown to inactivate completely any LIF present ${ }^{918}$ and served as an LIF-inactivated supernatant. MNC culture medium was used as lymphokine-free control.

$50 \mu \mathrm{l}$ of test supernatant, LIF-inactivated supernatant, or culture medium was mixed with $50 \mu \mathrm{l}$ of the PML suspension and preincubated for $45 \mathrm{~min}$ at $37{ }^{\circ} \mathrm{C}$ in $100 \%$ humidity and $5 \% \mathrm{CO}_{2}$. Thereafter each agarose gel well was filled with $10 \mu l$ of the preincubated PML/supernatant mixture, $8 \times 10^{5}$ PML/well. Each gel plate of 14 wells contained 7 wells with PML mixed with either test supernatant or LIF-inactivated supernatant from one MNC culture, and in the other 7 wells were PML exposed 
to LIF-inactivated supernatant from the same MNC culture or to culture medium alone. In this way the variation of the method was reduced in comparison with that when using several gel plates with fewer wells each.

The agarose gel plates were incubated for 17 hours at $37^{\circ} \mathrm{C}$ in $100 \%$ humidity and $5 \% \mathrm{CO}_{2}$. The plates were thereafter fixed in $7.5 \%$ glutaraldehyde for $30 \mathrm{~min}$, gels were removed, and plates were allowed to dry after gently washing in distilled water. The migration areas of PML were measured planimetrically. The mean migration area was calculared from migration areas from 7 wells on one plate and was compared with the mean area of the other 7 migration areas on the same plate. Migration indices (MI) were determined in 3 different ways to allow comparison between the capability of test supernatants, LIF-inactivated supernatants, or culture medium to affect PLM migration.

$$
\begin{aligned}
& \mathrm{MI}_{1}=\frac{\begin{array}{c}
\text { mean migration area of PML in the presence of test } \\
\text { supernatant }
\end{array}}{\begin{array}{c}
\text { mean migration area of PML in the presence of LIF- } \\
\text { inactivated supernatant }
\end{array}} \\
& \mathrm{MI}_{2}=\frac{\begin{array}{l}
\text { mean migration area of PML in the presence of test } \\
\text { supernatant }
\end{array}}{\text { mean migration area of PML in the presence of }} \\
& \mathrm{MI}_{3}=\frac{\text { medium }}{\text { mean migration area of PML in the presence of }} \\
& \text { medium }
\end{aligned}
$$

STATISTICAL EVALUATION

The standard deviation of the mean MI of each gel plate were calculated according to the formula used by Yoshida et al. ${ }^{19}$ Statistical evaluation of the difference between the mean migration indices of the supernatants from synovial tissue $\mathrm{MNC}$ and patient and normal blood MNC were done by MannWhitney $U$ test. Significance was set at $p<0.05$. A positive MI was defined as values higher or lower than 2 standard deviations from the mean MI of normal blood MNC supernatants.

\section{TESTS FOR NON-SPECIFIC FACTORS}

AFFECTING THE MIGRATION

Culture medium was also exposed to $80^{\circ} \mathrm{C}$ for 30 min and compared with unheated medium for any effect on PML migration. In addition, aggregated IgG was added to the medium in final concentrations of 25 and $50 \mu \mathrm{g} / \mathrm{ml}$. Half of these solutions were exposed to $80^{\circ} \mathrm{C}$ for $30 \mathrm{~min}$, and all were compared to unheated MNC medium. Aggregated IgG was prepared by exposing a solution of $10 \mathrm{mg} / \mathrm{ml}$ of
IgG (Kabi, Sweden) to $63^{\circ} \mathrm{C}$ for $15 \mathrm{~min}$ and subsequent rapid cooling in an ice bath. The solution was filtered through a $0.22 \mu \mathrm{m}$ Millipore filter (Millipore Corp., USA) before use.

Two blood MNC samples also underwent the same enzymatic treatment as the synovial tissue $\mathbb{D}$ MNC and were compared with the corresponding Isopaque-Ficoll-separated $\mathrm{MNC}$ with respect to viability or release of factors affecting the migration of homologous PML.

TEST FOR RHEUMATOID FACTOR

This was performed by the routine Waaler-Rose test of this laboratory, with group $O$ human erythrocytes sensitised with rabbit antibodies.

\section{Results}

\section{LIF ACTIVITY OF THE SUPERNATANTS}

The presence of LIF is revealed when the effect of PML migration of a test supernatant is compared $\stackrel{c}{c}$ with that of the corresponding LIF-inactivated supernatant. Hence the presence of LIF is expressed as

$$
M I_{1}=\frac{\text { test supernatant }}{\text { LIF-inactivated supernatant }} .
$$

The mean $\mathrm{MI}_{1}$ of 9 supernatants from the cultures of synovial tissue MNC was $0 \cdot 83 \pm 0.04$ (mean \pm SD), $\frac{\AA}{\varnothing}$ which was significantly lower than the mean $\mathrm{MI}_{1}$ of 8 normal blood MNC supernatants of $0.99 \pm 0.06 \overrightarrow{\overrightarrow{0}}$ $\left(p<0.001\right.$, Table 1). The normal range of $M I_{1}$ of 3 normal blood MNC supernatants (mean \pm 2 SD) was $0 \cdot 87-1 \cdot 11$, and all $\mathrm{MI}_{1}$ of the synovial tissue MNC supernatants were at or below this range (Fig. 1). The mean $\mathrm{MI}_{1}$ of 7 patient blood MNC supernatants was $0.96 \pm 0.08$. This was significantly 3 . higher than the mean $\mathrm{MI}_{1}$ of synovial tissue MNC supernatants $(p<0.002$, Table 1$)$ but did not differ from the mean $\mathrm{MI}_{1}$ of normal blood MNC super- 0 natants. Each of the $\mathrm{MI}_{1}$ of patient blood $\mathrm{MNC}$ supernatant was within the normal range of the $\frac{D}{0}$ normal blood MNC supernatants (Fig. 1).

This indicates that all synovial tissue MNC ${ }_{0}$ supernatants showed migration inhibition activity, $N$ while patient or normal blood MNC supernatants N did not inhibit the migration of homologous PML.

\section{LIF AND LEF ACTIVITY TOGETHER}

IN THE SUPERNATANTS

The effect of an enhancement activity of LEF is to reduce the effect of LIF, and the ratio

$$
\mathrm{MI}_{2}=\frac{\text { test supernatant }}{\text { medium }}
$$

should approach 1. 
Table 1 Mean migration indices* $\left(M I_{1-3}\right)$ of supernatants after 48, 72, or 96 hours of incubation of synovial tissue mononuclear cells $(M N C)$ from 5 patients with rheumatoid arthritis, 2 with juvenile rheumatoid arthritis, and 2 with psoriatic arthropathy. Mean MI-3 of blood MNC supernatants from 7 of the patients and 8 healthy blood donors are also shown together with the normal range (mean $\pm 2 S D$ ) of $M I_{1-3}$ of blood MNC supernatants from the healthy blood donors.

\begin{tabular}{|c|c|c|c|c|}
\hline & & $\begin{array}{l}M I_{1} \\
\text { Test sup. } \\
\text { LIF-ina. sup. }\end{array}$ & $\begin{array}{l}\mathrm{MI}_{2} \\
\text { Test sup. } \\
\text { Medium }\end{array}$ & $\begin{array}{l}\text { MI } I_{3} \\
\text { LIF-ina. sup. } \\
\text { Medium }\end{array}$ \\
\hline Patients & $\begin{array}{l}\text { Mean MI of } 9 \text { synovial tissue MNC sup. } \\
\text { Mean MI of } 7 \text { blood MNC supernatants }\end{array}$ & $\begin{array}{l}0.83 \pm 0.04 * * \\
0.96 \pm 0.08\end{array}$ & $\begin{array}{l}0.97 \pm 0.16 \\
1 \cdot 10 \pm 0.06\end{array}$ & $\begin{array}{l}1 \cdot 13 \pm 0 \cdot 18 \\
1 \cdot 14 \pm 0.08\end{array}$ \\
\hline $\begin{array}{l}\text { Healthy } \\
\text { blood donors }\end{array}$ & $\begin{array}{l}\text { Mean MI of } 8 \text { blood MNC supernatants } \\
\text { Normal range (mean } \pm 2 \text { SD) of MI of } 8 \text { blood MNC } \\
\text { supernatants }\end{array}$ & $\begin{array}{l}0.99 \pm 0.06 \\
0.87-1.11\end{array}$ & $\begin{array}{l}1.02 \pm 0.09 \\
0.84-1.20\end{array}$ & $\begin{array}{l}1.05 \pm 0.06 \\
0.94-1 \cdot 17\end{array}$ \\
\hline
\end{tabular}

*Mean migration indices are written mean \pm SD. $\mathbf{M I}_{1}=$ test supernatant/LIF-inactivated supernatant, $\mathbf{M I}_{2}=$ test supernatant/medium, $\mathrm{MI}_{3}=$ LIF-inactivated supernatant $/$ medium.

${ }^{* *}$ Statistically different from mean $\mathrm{MI}_{1}$ of blood MNC supernatants from the patients $(\mathrm{P}<0.002)$ and the healthy blood donors $(\mathrm{P}<0.001)$ (Mann-Whitney test).

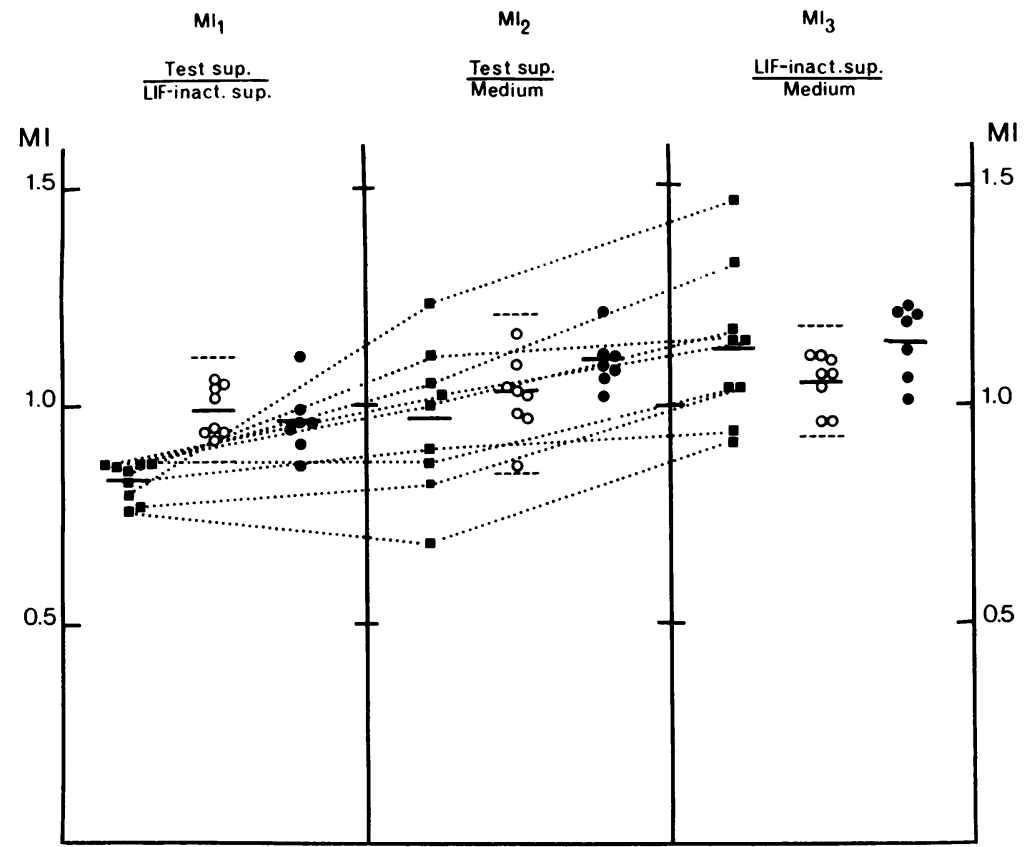

Fig. 1 Individual migration indices $\left(M I_{1-3}\right)$ of supernatants from 48 to 96 h of cultures of synovial tissue mononuclear cells $(M N C)$ from 5 patients with rheumatoid arthritis, 2 with juvenile rheumatoid arthritis, and 2 with psoriatic arthropathy ( $\square)$, and of blood MNC supernatants from 7 of the patients $(\bullet)$ and from 8 healthy individuals $(\mathrm{O})$. Mean $M I_{1-3}$ are indicated by horizontal lines, and normal range of $M I$ (mean $\pm 2 S D)$ of normal blood MNC supernatants by broken lines. Individual $M_{1-3}$ of synovial tissue MNC supernatants are connected by dotted lines.

The mean $\mathrm{MI}_{2}$ of synovial tissue MNC supernatants $(0.97 \pm 0 \cdot 16)$ did not differ significantly from the mean $\mathrm{MI}_{2}$ of normal blood MNC supernatants $(1.02 \pm 0.09)$ or of patient blood MNC supernatants $(1 \cdot 10 \pm 0 \cdot 06)$ (Table 1). However, there was a large variation in $\mathrm{MI}_{2}$ of individual synovial tissue MNC supernatants, the 2 extremes of patients 7 and $1(0.69$ and $1 \cdot 23$ respectively) being outside the normal range of $\mathrm{MI}_{2}$ of normal blood MNC supernatants $(0 \cdot 84-1 \cdot 20)$ (Fig. 1).

\section{LEF ACTIVITY ALONE}

When the supernatants are inactivated for LIF activity, the effect of an enhancement activity could be studied by the ratio

$$
\mathrm{MI}_{3}=\frac{\text { LIF-inactivated supernatant }}{\text { medium }}
$$

There was no difference between the mean $\mathrm{MI}_{3}$ of synovial tissue MNC supernatants $(1 \cdot 13 \pm 0 \cdot 19)$, of normal blood MNC supernatants $(1 \cdot 05 \pm 0 \cdot 06)$, or of patient blood MNC supernatants $(1 \cdot 14 \pm 0 \cdot 08)$ (Table 1). However, patients 1 and 2 scored very high values of $\mathrm{MI}_{3}$ of synovial MNC supernatants ( 1.47 and 1.32 , respectively). The other $\mathrm{MI}_{3}$ were within or at the normal range limit of normal blood MNC supernatants $(0 \cdot 93-1 \cdot 17)$ (Fig. 1). 
Table 2 Migration indices* $\left(M I_{1-3}\right)$ of synovial tissue mononuclear cells $(M N C)$ supernatants of 9 patients studied. Diagnosis,** serum Waaler-Rose titre of rheumatoid factor, and duration of MNC incubation are also shown. The presence of leucocyte migration inhibitation factor $(L I F)$ and leucocyte migration enhancement factor $(L E F)$ is indicated.

\begin{tabular}{|c|c|c|c|c|c|c|c|c|}
\hline Patient & Diagnosis & $\begin{array}{l}\text { Serum } \\
\text { Waaler-Rose } \\
\text { titre }\end{array}$ & $\begin{array}{l}\text { Duration } \\
\text { (hours) of } M N C \\
\text { incubation }\end{array}$ & $\begin{array}{l}M I_{1} \\
\text { Test sup. } \\
\text { LIF-ina. sup. }\end{array}$ & $\begin{array}{l}\mathrm{MI}_{2} \\
\text { Test sup. } \\
\text { Medium }\end{array}$ & $\begin{array}{l}\mathrm{MI}_{3} \\
\text { LIF-ina. sup. } \\
\text { Medium }\end{array}$ & $\begin{array}{l}\text { Prese } \\
\text { L.IF }\end{array}$ & $\begin{array}{l}\text { of } \\
L E F\end{array}$ \\
\hline
\end{tabular}

* Migration indices (MI) are written mean \pm SD. $\mathbf{M I}_{1}=$ test supernatant $/ \mathrm{LIF}$-inactivated supernatant, $\mathrm{MI}_{2}=$ test superna tant $/ \mathrm{medium}$ and $\mathrm{Ml}_{3}=$ LIF-inactivated supernatant $/$ medium .

**RA $=$ rheumatoid arthritis, JRA = juvenile rheumatoid at thritis, PA = psoriatic arthropathy.

When $\mathrm{MI}_{3}$ and also $\mathrm{MI}_{2}$ were examined (Table 2), an enhancement activity competing with LIF seemed to be present in some synovial tissue MNC supernatants. For patients 1 and 2 this enhancement activity appeared to be rather strong (high $\mathrm{MI}_{2}$ and $\mathrm{MI}_{3}$ values). Except for patients 3, 5, and 6, who possibly also showed some enhancement activity in their synovial tissue MNC supernatants, the left 4 supernatants did not show any such activity.

INFLUENCE OF VARIABLE TIME OF SYNOVIAL MNC INCUBATION ON MI

$\mathrm{MI}_{1,2}, 3$, of synovial tissue MNC supernatant for patient 2 after 24, 48, 72, and 120 hours of incubation are illustrated in Fig. 2. After $24-48 \mathrm{~h}$ of incubation no inhibiting effect was recovered. As the time of incubation was further extended, $\mathrm{MI}_{1}$ (test supernatant/LIF-inactivated supernatant) decreased below the normal range of $\mathrm{MI}_{1}$ of normal blood MNC supernatants. Comparison of the migration effect on the test supernatants against the oifect of modium shomed that $\mathrm{MI}_{2}$ numcieally abo decreaned over a period of days. MIs homanr, gradually increased to high values above the normal range of $\mathrm{MI}_{3}$ of normal blood $\mathrm{MNC}$ supernatants. On the whole after 3-5 days of synovial tissue MNC incubation the supernatant seemed to contain activities capable of affecting the migration of homologous PML in both an inhibitory and a stimulatory way.

As the time of synovial tissue MNC incubation passed 24, 28, and $96 \mathrm{~h}$, the supernatant of patient 7 gradually increased in LIF activity (decreased $\mathrm{MI}_{1}$, Fig. 2). When we tested the supernatant after $96 \mathrm{~h}$ of incubation no enhancement activity was recovered (low $\mathrm{MI}_{2}$ and $\mathrm{MI}_{3}$ ).

As controls supernatants of blood MNC from 2 healthy individuals were also studied in the same way. Fig. 2 shows that even after a long period of incubation their supernatants did not show any activity inhibiting or stimulating PML migration.

EFFECT OF OPERATION ON BLOOD MNC

Blood MNC from 3 female patients with RA were minaved 1 day before and 1, day after the operation. Afer 72 hours of incubation neither MNC taken

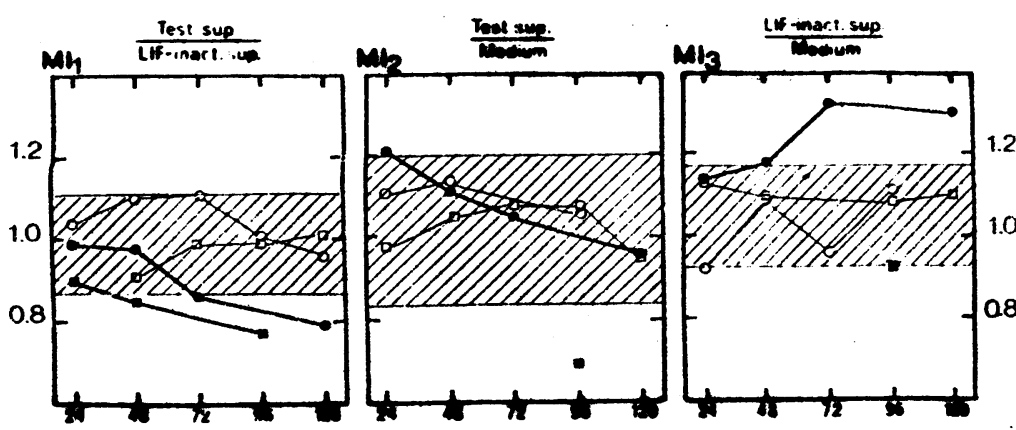

Duration (hrs) of incubation of MinC
Fig. 2 Duration of incubation of synovial tissue mononuclear cells $(M N C)$ from patients 2 ( $\mathrm{O})$ and 7 ( $\square$ ) versus migration indices $M I_{1-3}$. The results of blood MNC from 2 healthy individuals are also shown ( $\bigcirc$ and $\square$ ). Normal range of $M I($ mean $\pm 2 S D)$ of 8 normal blood $M N C$ supernatants after 48-72 $h$ of incubrian is hatched. 
before nor MNC taken after the operation released any PML migration inhibition or enhancement activity. Two of the patients had general anaesthesia, and the third was anaesthetised with nerve block. The patients received gold thiomalate or prednisone together with anti-inflammatory drugs.

\section{TESTS FOR NONSPECIFIC FACTORS}

AFFECTING THE MIGRATION OF PML

With respect to the effect on the migration of PML, neither unheated or heated $\left(80^{\circ} \mathrm{C}, 30 \mathrm{~min}\right)$ aggregated IgG-containing medium nor heated medium differed from the effect of medium alone. In addition, 2 blood MNC samples undergoing enzymatic treatment of the synovial cells elution method did not differ from the corresponding Isopaque-Ficoll-separated MNC with regard to release of LIF. The viability of these 2 differently treated samples of MNC both exceeded $90 \%$ before and after MNC incubation of 2 or 3 days.

During the incubation there was a reduction in viability from $75 \%$ to $50 \%$ in some synovial tissue MNC cultures. However, cell death per se was excluded as a cause of LIF release, since the degree of reduction in viability of the individual MNC cultures was not correlated with inhibotory effect of their supernatants.

\section{CORRELATION WITH SERUM WAALER-ROSE}

TITRE OF RHEUMATOID FACTOR OR DRUGS From Table 2 it is clear that there was no correlation between the patients' titre of rheumatoid factor and the presence of LIF (or LEF). In addition, the drugs that were used did not seem to affect the release of LIF (or LEF).

\section{Discussion}

In the 9 patients studied LIF was found in the supernatants of all cultures of eluted synovial tissue MNC. The cells were not exposed to any known in-vitro stimulation of antigens or mitogens. Supernatants of cultures of blood MNC from the same patients or healthy individuals did not contain any detectable LIF under the same culture conditions.

The indirect leucocyte migration inhibition test can detect small amounts of LIF. ${ }^{12}$ Since mean MI $_{1}$ (test supernatant/LIF-inactivated supernatant) of synovial tissue MNC was not lower than $0 \cdot 83$, LIF was not present in large amounts. When supernatants of antigen-stimulated cultures of blood MNC are compared with antigen-free cultures, positive inhibitory activity is usually at values below $0 \cdot 80$ or even $0 \cdot 70{ }^{20} 21$ However, the major point in our study is that supernatants of synovial tissue MNC behaved differently from blood MNC of the patients and healthy individuals with regard to inhibitory effect on PML migration. Enzymes used for elution, immunocomplexes, or heating of the supernatants for LIF inactivation ${ }^{918}$ were ruled out as explanations for the observed difference, since, in accordance with the findings of Chattopadhyay et al.,11 enzyme-treated blood MNC, heating of the medium, or heat-aggregated $\mathrm{IgG}^{22}$ did not affect PML migration. Nor was the observed reduction in synovial tissue MNC viability during incubation thought to cause LIF release, since there were no correlations between the relative amount of cell death and inhibitory activity of the supernatants.

When blood lymphocytes are studied, the production of LIF is regarded as a function of sensitised $T$ lymphocytes in response to antigens, while both $B$ and $T$ lymphocytes can release LIF after mitogenic stimulation. ${ }^{723}$ In addition the presence of monocytes is probably necessary for a T-cell response after antigen stimulation. ${ }^{23}$ The eluted synovial tissue MNC are poorly characterised. However, it seems that these cells are made up of large numbers of lymphocytes, mainly $T$ lymphocytes and monocyte/macrophage-like cells. ${ }^{1}$

Because PML migration inhibition activity was found in the supernatants of synovial tissue MNC, we believe that LIF was released by the eluted synovial lymphocytes, but the stimulus for this release is a matter for speculation.

Chattopadhyay et al. ${ }^{24}{ }^{25}$ have shown that the eluted synovial tissue MNC of patients with RA lack suppressor T-cell activity. Whether this means that production and/or secretion of lymphokines such as LIF are more easily triggered off or not is unknown. If the triggering threshold is decreased, it is possible the enzymatic elution treatment could have set off the release of LIF by synovial tissue MNC, while blood MNC are unaffected by the same enzymes. It is even possible that an interaction between the various eluted inflammatory cell populations might have triggered the release of LIF. Nevertheless, it is still an attractive hypothesis that the eluted cells have been stimulated in vivo by a hitherto unknown local agent. This hypothesis fits the findings of Stastny et al., ${ }^{5}$ who observed lymphokine activities of macrophage migration inhibition factor and lymphocyte mitogenic factor in a high proportion of synovial fluids and supernatants of cultured minced synovial tissue from RA patients. In the present study the cells seemed to continue to release immune mediators as LIF in vitro. In addition LIF release was the same for the synovial tissue MNC of the 3 categories of disorders investigated.

Although our study confirms the observations of Chattopadhyay et al. ${ }^{11}$ that synovial tissue MNC can release LIF under antigen- and mitogen-free 
culture conditions, we could not verify the correlation between LIF release and Waaler-Rose titre of rheumatoid factor in the patients' sera. This discrepancy may be partly explained by the short incubation time of 24 hours in Chattopadhyay et al.'s studies, whereas kinetic experiments in 2 of our patients showed that their synovial tissue MNC needed 47-72 $\mathrm{h}$ of incubation to release detectable LIF (Fig. 2). The various synovial tissue MNC incubation times of 48,72 , or $96 \mathrm{~h}$ of the 9 patients studied did not interfere with the conclusion that their synovial tissue MNC released LIF. Actually, if all the incubations had lasted for $96 \mathrm{~h}$, the mean $\mathrm{MI}_{1}$ might have been even lower.

We have also showed that the patients' blood MNC did not release LIF under the same antigenand mitogen-free culture conditions but rather behaved in the same way as blood MNC from healthy individuals. Hence there seems to be a basic difference between the conditions of the infiltrating and circulating $\mathrm{MNC}$, which might indicate that RA and related arthritides are maintained by pathological agents localised in the joint tissue.

Since blood MNC samples for practical reasons had to be isolated from samples drawn 1 or a few days after the operation, the behaviour of blood MNC might have been influenced by the postoperative state. However, results on blood MNC from 3 patients with RA obtained 1 day before and 1 day after the synovectomy showed no LIF release. Neither the operation, nor anaesthesia, nor the drugs that were used (prednisone, gold thiomalate, and anti-inflammatory drugs) set off LIF release from their blood MNC.

The above-mentioned PML migration enhancement activity of some of the synovial tissue MNC LIC-inactivated supernatants was never seen in blood MNC supernatants. Until LEF is better characterised it is difficult to interpret the observed migration stimulation.

T. Egeland is a research fellow supported by the Norwegian Women's Public Health Organisation. This study was also supported by the Norwegian Hydro Company. Thanks are due to the staff at the Surgical Department, Oslo Sanitetsforening Rheumatism Hospital, for providing tissue, and to Miss Marit Brevik and Mrs Marit Fallet for typing the manuscript.

\section{References}

1 Abrahamsen T G, Fröland S S, Natvig J B, Pahle J. Elution and characterization of lymphocytes from rheumatoid inflammatory tissue. Scand J Immunol 1975; 4: 823-30.

2 Munthe E, Natvig J B. Immunoglobulin classes, subclasses and complexes of IgG rheumatoid factor in rheumatoid plasma cells. Clin Exp Immunol 1972; 12: 55-70.

${ }^{3}$ Zvaifler N J. The immunopathology of joint inflammation in rheumatoid arthritis. In: Dixon F J, Kunkel H G, eds. Advances in Immunology. New York and London: Academic Press, 1973; 16: 265-336.

4 Smiley J D, Sachs C, Ziff M. In vitro synthesis of immunoglobulin by rheumatoid synovial membrane. J Clin Inve st 1968; 47: 624-32.

5 Stastny P, Rosenthal M, Andreis M, Ziff M. Lymphokines in the rheumatoid joint. Arthritis Rheum 1975; 18: 237-43.

6 Rocklin R E. Products of activated lymphocytes: leukocyte inhibitory factor (LIF) distinct from migration inhibitory factor (MIF). J Immunol 1974; 112: 1461-6.

7 Chess L, Rocklin R E, MacDermott R P, David J R, Schlossman S F. Leukocyte inhibitory factor (LIF): production by purified human $\mathrm{T}$ and $\mathrm{B}$ lymphocytes. J Immunol 1975; 115: 315-7.

8 Arvilommi H, Räsänen L. Spontaneous lymphokine synthesis by human blood mononuclear cells. Nature 1975; 257: 144-6.

- Palit J, Bendtzen K, Andersen V. Production of leukocyte migration inhibitory factor (LIF) in infectious mononucleosis. Spontaneous release and lack of response to concanavalin A. Clin Exp Immunol 1978; 31 : 66-71.

10 Pietruszka M, Rabin B S. Abnormality of spontaneous lymphokine synthesis by lymphocytes of patients with connective tissue disorders. Immunol Comm 1979; 8: 203-11.

11 Chattopadhyay H, Chattopadhyay C, Natvig J B, Mellbye O J, Pahle J. Spontaneous release of leukocyte migration inhibitory factor by mononuclear cells eluted from rheumatoid synovial tissue. Scand J Immunol 1980; 12: 475-9.

12 Clausen J E. Migration inhibitory effect of cell-free supernatants from tuberculin-stimulated cultures of human mononuclear leukocytes demonstrated by twostep MIF agarose assay. J Immunol 1973; 110: 546-51.

13 Söberg M. In vitro migration of peripheral human leukocytes in cellular hypersensitivity. Acta Med Scand 1968; 184: 135-9.

14 Tanaka K, Yamauchi Y, Horimatsu T, Isobe T, Imura H. Leukocyte migration inhibition test (LMIT) in systemic lupus erythematosus. Microbiol Immunol 1978; 22: 785-92.

15 Weisbart R H, Bluestone R, Goldberg L S, Pearson C M. Migration enhancement factor: a new lymphokine. Proc Natl Acad Sci USA 1974; 71: 875-9.

16 Böyum A. Separation of blood leukocytes, granulocytes and lymphocytes. Tissue Antigens 1974; 4: 269-74.

17 Anders E M, Natvig J B. Cell-mediated immunity to viruses measured by the indirect agarose technique of leukocyte migration inhibition. Cell Immunol 1976; 27 : 214-99.

18 Bendtzen K. Some physiochemical properties of human leukocyte migration inhibitory factor (LIF). Acta Pathol Microbiol Scand Sect C 1976; 84: 471-6.

19 Yoshida T, Janeway jr C A, Paul W E. Activity of migration inhibitory factor in the absence of antigen. J Immunol 1972; 109: 201-6.

20 Chattopadhyay H, Chattopadhyay C, Natvig J B. Hyporesponsiveness to virus antigens in rheumatoid synovial and blood lymphocytes using the indirect leukocyte migration inhibition test. Scand J Immunol 1979; 10: 585-92.

21 Yoshida T, Cohen S. Lymphokine activity in vivo in relation to circulating monocyte levels and delayed skin reactivity. J Immunol 1974; 112: 1540-7. 
22 Kemp A S, Brown S. Inhibition of neutrophil migration by aggregated immunoglobulin attached to micropore membranes. Immunology 1980; 39: 529-34.

23 Räsänen L. Cellular co-operation in the production of human leukocyte inhibitory factor by lymphocyte subpopulations stimulated with antigens and allogeneic cells. Immunology 1979; 37: 715-21.
24 Chattopadhyay C, Chattopadhyay H, Natvig J B, Michaelsen T E, Mellbye $O$ J. Lack of suppressor cell activity in rheumatoid synovial lymphocytes. Scand $J$ Immunol 1979; 10: 309-16.

25 Chattopadhyay C, Chattopadhyay H, Natvig J B, Mellbye $O \mathrm{~J}$. Rheumatoid synovial lymphocytes lack concanavalin-A-activated suppressor cell activity. Scand J Immunol 1979; 10: 479-86. 